\title{
Why Pedestrian-Friendly Street Design is Not Negligent
}

Michael Lewyn

Touro Law Center, mlewyn@tourolaw.edu

Follow this and additional works at: https://digitalcommons.tourolaw.edu/scholarlyworks

Part of the Civil Law Commons, and the State and Local Government Law Commons

\section{Recommended Citation}

47 U. Louisville L. Rev. 339 (2008)

This Article is brought to you for free and open access by the Faculty Scholarship at Digital Commons @ Touro Law Center. It has been accepted for inclusion in Scholarly Works by an authorized administrator of Digital Commons @ Touro Law Center. For more information, please contact Iross@tourolaw.edu. 


\section{HEINONLINE}

Citation: 47 U. Louisville L. Rev. 339 2008-2009

Content downloaded/printed from

HeinOnline (http://heinonline.org)

Mon Aug 15 15:05:02 2011

-- Your use of this HeinOnline PDF indicates your acceptance of HeinOnline's Terms and Conditions of the license agreement available at http://heinonline.org/HOL/License

-- The search text of this PDF is generated from uncorrected OCR text.

-- To obtain permission to use this article beyond the scope of your HeinOnline license, please use:

https://www.copyright.com/ccc/basicSearch.do?

\&operation $=$ go\&search Type $=0$

\&lastSearch $=$ simple\&all=on\&titleOrStdNo $=1531-0183$ 


\title{
WHY PEDESTRIAN-FRIENDLY STREET DESIGN IS NOT NEGLIGENT
}

\author{
Michael Lewyn*
}

American streets are not always made for walking. Major streets can be as many as eight or ten lanes wide, ${ }^{1}$ lengthening pedestrian trips ${ }^{2}$ and preventing slow-moving pedestrians from crossing in time to avoid speeding cars. Because automobiles may rush through these wide streets at forty or fifty miles per hour, ${ }^{3}$ any collision is likely to be fatal for a pedestrian or bicyclist. ${ }^{4}$

In part, the anti-pedestrian design of American streets is a result of American tort law, or more accurately, of transportation planners' perceptions of American tort law. A motorist injured in a collision may sue a state or local government, or its employees, for negligent street design. ${ }^{5}$ In negligent street

- Assistant Professor, Florida Coastal School of Law. B.A., Wesleyan University, J.D., University of Pennsylvania. I would like to thank Elizabeth DeCoux, Michael Ronkin, Billy Hattaway, Andrew Fischer, Stephen Burrington, and Carolyn Herman for their comments and suggestions; however, any error of law, fact, or reasoning is mine alone.

${ }^{1}$ See, e.g., Sally Cragin, L.A. Shines with Many Alternatives to Disneyland, Boston HERALD, Aug. 25, 1996, at 67, available at 1996 WLNR 262869 (major surface streets in Los Angeles are typically six to eight lanes wide); Jim Schaefer, Walking the Whole Way up Woodward: The Avenue from Detroit to Pontiac is Paved with 26 Miles of History-and it's Celebrating its 200th Anniversary, DETROIT FREE PrESS, Aug. 17, 2007, available at 2007 WLNR 15984999 (Woodward Avenue, a major street in Detroit, is ten lanes wide); Susan Warner, Trials of Travel on City Avenue, PHILA. INQUIRER, Feb. 26, 1987, at M05, available at 1987 WLNR 533119 (Philadelphia's City Avenue is eight lanes wide).

${ }^{2}$ See Donavan v. Jones, 658 So. 2d 755, 765 (La. Ct. App. 1995) (quoting expert testimony that wider streets take longer to cross).

${ }^{3}$ See, e.g., Nicholas Grudin, Putting on the Brakes: Parents Lobby to Cut Speed Limit Near School, L.A. DAII Y NEWS, Dec. 18, 2003, at 1, available at 2003 WLNR 2666598 (road in front of one Los Angeles-area elementary school has a speed limit of fifty miles per hour); Sarah Ovaska, Resident Wants 'At Least a Signal Light' to Safeguard Schoolchildren, THE NEws \& OBSERVER, Feb. 2, 2008, at B1, available at 2008 WLNR 2004949 (schoolchildren must cross Wake Forest Road in Raleigh, North Carolina, to reach elementary school, yet " $40 \mathrm{mph}$ traffic headed to and from downtown often zips by without slowing").

${ }^{4}$ See Stephen H. Burrington, Restoring the Rule of Law and Respect for Communities in Transportation, 5 N.Y.U. ENVTL. L.J. 691,704 (1996) (explaining why fast traffic is dangerous to pedestrians); infra notes 37-43 and accompanying text.

${ }^{5}$ See 40 AM. JUR. 2D Highways, Streets, and Bridges $\$ 382$ at 878 (2008) ("liability of a public authority may, in certain circumstances, be based on a negligent design defect in a highway or bridge"); U.S. Department of Transportation - Federal Highway Administration, 
design cases, courts and juries may rely ${ }^{6}$ upon guidelines set by the American Association of State Highway and Transportation Officials (AASHTO), ${ }^{7}$ which is a national association of government transportation officials. ${ }^{8}$ As a result, state and local transportation planners rely on AASHTO guidelines in order to avoid tort liability. ${ }^{9}$ Because AASHTO's street-design rules have historically favored wide streets built to accommodate high-speed traffic, ${ }^{10}$ planners sometimes assume that in order to avoid liability, they must do the same. ${ }^{11}$

The purpose of this Article is to disprove that theory and instead show that under American tort law, transportation planners can make streets safer and more comfortable for pedestrians without risking additional liability exposure. This is so for two reasons. First, the policy decisions of local governments that allow more pedestrian-friendly street design are likely protected from tort liability under the "discretionary immunity" doctrine because the doctrine exempts policy-related decisions from tort liability. ${ }^{12}$ Transportation planners

Highway Design Standards, ch. 2, http://www.fhwa.dot.gov/environment/flex/ch02.htm (describing tort liability as "a real concern for highway engineers") (last visited Mar. 3, 2009).

${ }^{6}$ See Shilling v. Louisiana, 928 So. 2d 95, 100 (La. Ct. App. 2005) (AASHTO standards are a "relevant factor in determining the ultimate issue of whether a roadway is dangerous." (quoting Aucoin v. Louisiana, 712 So. 2d 62, 66 (La. 1998))); Sweet v. Seekonk Planning Bd., No. 286204, slip op. at*8 (Mass. Land Ct. Dec. 21, 2006), available at 2006 WL 3740615 (noting that AASHTO standards "provide valuable evidence of good street design"); Dan Christensen, Paving the Way for a Road Hazard Case, TRIAL, Jan. 1, 2002, 47-48 (noting that AASHTO is "the nation's primary publisher of roadway and roadside design policies and guidelines" and that "their publications can be persuasive in roadway hazard cases"); infra note 8.

${ }^{7}$ See generally AM. Ass'N OF STATE HighWAY ANd Transportation OfFiCials, A POLICY ON GEOMETRIC DESIGN OF HIGHWAYS AND STREETS (5th ed. 2004) [hereinafter AASHTO 2004].

${ }^{8}$ See Ctr. for Auto Safety v. Cox, 580 F.2d 689, 690 (D.C. Cir. 1978) ("AASHTO is an organization of state and federal transportation officials, established in 1914, to foster the development of a nationwide integrated transportation system. The active membership consists of the heads of the various state transportation departments.").

${ }^{9}$ See Alan Ehrenhalt, The Asphalt Rebellion, GREENSBORO NEws \& RECORD, Apr. 12, 1998, at F1, available at 1998 WLNR 7284176 ("One thing any local board or council knows for sure is that if it builds a road according to AASHTO standards, it will not be sued for design negligence in the event of an accident.").

${ }^{10}$ See infra notes 23-24, 31-33 and accompanying text.

" Conservation Law Foundation, Take Back Your Streets: How to Protect Communities from Asphalt and Traffic ch. 3, http://www.clf.org/general/index.asp?id=386 (last visited Mar. 4,2009 ) ("The highway department may resist your request for flexible" and pedestrian-oriented highway design "by citing concerns about liability."). I recognize that in theory, an injured pedestrian could claim that government officials' decision to design streets for high-speed traffic was negligent, but if those same officials followed AASHTO standards, such a claim would be unlikely to succeed. See Ehrenhalt, supra note 9 (noting that governments that follow AASHTO standards are unlikely to lose negligent design lawsuits).

${ }^{12}$ See infra Part II.A. 
may therefore disregard AASHTO guidelines without fear of tort liability if their deviation is based on a deliberate policy decision to make streets more pedestrian-friendly. Second, the most recent AASHTO manual gives government officials significant discretion to create more pedestrian-friendly streets. Accordingly, transportation planners are free to follow AASHTO guidelines and still make streets more pedestrian-friendly without the same risk of tort liability.

Part I of this Article explains the evolution of AASHTO guidelines and describes their impact upon American pedestrians and bicyclists. Part II shows why those guidelines do not require transportation planners to ignore the interests of non-drivers in order to avoid tort liability. Part III explains why, as a matter of policy, transportation planners should use their discretion to create more pedestrian-friendly streets.

\section{BACKGROUND: THE RISE OF AASHTO AND WHY IT MATTERS}

This Article focuses on (a) AASHTO's street-design guidelines and (b) how the American tort system affects the interests of non-drivers. The first factor has become less important over time, as AASHTO's guidelines have become more flexible. ${ }^{13}$ The second factor, however, has become more important as states have abridged the scope of sovereign immunity that once protected state and local governments from being sued for negligent highway design. $^{14}$

\section{A. The Evolution of AASHTO Guidelines}

For most of the twentieth century, AASHTO guidelines favored rules that allowed traffic to move as fast as possible, regardless of the consequences. ${ }^{15}$ Because the federal government mandated that state and local governments follow these guidelines for federally funded roads, ${ }^{16}$ AASHTO's rules were highly influential. In recent years, however, these guidelines have become both less important and less auto-oriented: less important because the federal government has recently given state and local officials more flexibility in designing federally funded streets than in the past, ${ }^{17}$ and less auto-oriented

${ }^{13}$ See infra notes 68-84, 208-12 and accompanying text.

${ }^{14}$ See infra notes $125-37$ and accompanying text.

${ }^{15}$ See infra notes 23-51 and accompanying text.

${ }^{16}$ See Burrington, supra note 4, at 728.

${ }^{17}$ See infra notes 52-55 and accompanying text. 
because AASHTO's own guidelines are now considering the interests of nondrivers to a greater degree than in the past. ${ }^{18}$

\section{Speed Demons: The Rise of AASHTO}

State and local highway officials formed AASHTO (then known as AASHO, or the American Association of State Highway Officials) ${ }^{19}$ in $1914 .^{20}$ Initially, AASHO's primary goal was to lobby the federal government to increase highway spending. ${ }^{21}$ As early as 1931, though, AASHO began drafting road design guidelines. ${ }^{22}$ In 1957, AASHO published a manual proposing that major streets have at least six to eight twelve-foot lanes ${ }^{23}$ several times the width of typical pre-World War II streets. ${ }^{24}$ Excessively wide streets make non-automotive travel more difficult and dangerous because wide streets take longer for pedestrians and bicyclists to cross than narrower streets, exposing non-drivers to more high-speed traffic. ${ }^{25}$ Moreover, every additional lane of traffic increases a pedestrian's risk of being hit by a motor vehicle, since to avoid a collision, pedestrians must find a safe "gap" between their bodies and moving vehicles in each individual lane crossed ${ }^{26}$ - a task that becomes more

${ }^{18}$ See infra notes 67-84, 208-12 and accompanying text.

${ }^{19}$ See Snearl v. Mercer, 780 So. 2d 563, 576 (La. Ct. App. 2001) (noting AASHTO's former title).

${ }^{20}$ See Jay S. Bybee, Advising the President: Separation of Powers and the Federal Advisory Committee Act, 104 YALE L.J. 51, 84 n.172 (1994); Richard F. Weingroff, For the Common Good: The 85th Anniversary of a Historic Partnership, PUBLIC ROADS, Apr. 30, 2001, at 30, available at 2001 WLNR 4545358 (describing AASHTO's birth in more detail).

${ }^{21}$ Id. (describing AASHTO's support for the Federal Road Aid Act of 1916).

${ }^{22}$ See John C. Glennon, Roadway Defect Claims, Ass'N OF TrIal Lawyers of AM. ANNUAL CONVENTION REFERENCE MATERIALS, July 2001, at 765, available at 1 Ann. 2001 ATLA-CLE 765 (indicating that AASHTO has issued "a succession of publications from 1931 to 1994 " addressing highway safety issues). (2006).

${ }^{23}$ See Michael Lewyn, New Urbanist Zoning for Dummies, 58 ALA. L. REv. 257, 265

${ }^{24}$ See Ehrenhalt, supra note 9 ("In the early 20 th century, most urban streets and roadways in America were built between 18 and 24 feet wide."). In addition, AASHTO recommended that on-street parking be banned from major streets. See Lewyn, supra note 23, at 265 . The removal of off-street parking effectively widens streets by eliminating a "buffer zone" of parked cars that can protect pedestrians from auto traffic, thereby increasing the number of lanes a pedestrian must cross in order to cross a street. See Frank Jaskiewicz, Pedestrian Level of Service Based on Trip Quality G-1/6, http://onlinepubs.trb.org/onlinepubs/circulars/ ec019/Ec019_gl.pdf (On-street parking "serves as a continuous solid barrier between pedestrians and fast-moving vehicles.").

${ }^{25}$ See supra notes 2-4 and accompanying text.

${ }^{26}$ See FED. HighWAY ADMIN., MID-BLOCK CROSSINGS 16.4, http://safety.fhwa.dot.gov/ 
complex as the number of lanes multiplies, as pedestrians must make multiple "gap assessments." For instance, a pedestrian has to make a gap assessment only twice for a two-lane road, but six times for a six-lane road. ${ }^{27}$

In 1973, AASHO was renamed AASHTO to reflect the fact that its membership included transportation officials outside highway departments. ${ }^{28}$ Nevertheless, AASHTO's guidelines have continued to focus on the interests of motorists. The 1994 edition ${ }^{29}$ of AASHTO's "Policy on Geometric Design of Highways and Streets" - commonly known as the "Green Book"30-provides that the goal of street design is to create "operational efficiency, comfort, safety, and convenience for the motorist." should be made to use as high a design speed as practicable",32 -in other words, that roads should be designed to accommodate fast driving regardless of speed limits. ${ }^{33}$ State and local governments have generally followed the Green Book's guidelines, ${ }^{34}$ partially because until 1991 the federal government required state and local governments to do so when building federally funded road projects. ${ }^{35}$ And as noted above, ${ }^{36}$ state courts consider compliance with

ped_bike/univcourse/pdf/swless16.pdf [hereinafter MID-BLOCK] ("The pedestrian faced with one or more lanes of traffic in each direction must determine a safe gap in two, four or even six lanes at a time ... . Many may predict that a car is 61 meters ( 200 feet) off when, in fact, it is only 31 meters ( 100 feet), far too close to attempt a crossing.").

${ }^{27}$ See City of St. Petersburg-Triple E COMMITtee, BicyCle and Pedestrian SAfETy: A CALL To ACTION 13 (2002), http://stpeteshines.stpete.org/projects/spedd/18SPEDD121702/

BikePedestrianMasterPlan.pdf("Each additional lane to cross complicates ... gap assessment for pedestrians . . . ."); cf. MID-BLOcK, supra note 26 (Medians make pedestrians safer by creating "acceptable gaps" for pedestrians; instead of having to judge gaps in four lanes at a time, a pedestrian need only examine two two-lane gaps.).

${ }^{28} \mathrm{See}$ William Kaszynski, The American Highway: The History and Culture of ROADS IN THE UNITED STATES 170 (2000) (organization renamed "to include transportation officials, whether or not they were highway-related").

${ }^{29}$ Burrington, supra note 4, at 694 n. 14 (citing to 1994 edition of Green Book, and thus implicitly pointing out that citations are to the 1994 version unless otherwise specified).

${ }^{30}$ Id. at 695 n. 19 (using term "Green Book").

${ }^{31} I d$. at 694 (emphasis added) (citation omitted).

${ }^{32}$ Id. at 698 (citation omitted).

${ }^{33} I d$. ("Engineers usually set design speeds higher than the anticipated speed limit . . . to provide a margin of safety for motorists exceeding the speed limit.").

${ }^{34}$ Id. at 729 ("Most states still use the AASHTO guidelines . . . ."); see also Christensen, supra note 6, at 47 ("Most states base their highway design regulations on the many AASHTO books and reports published over the last 50 years."). But see Reid Ewing, From Highway to My Way, PlannING, Jan. 1, 2001, at 22 (describing some states' deviation from AASHTO guidelines).

\footnotetext{
${ }^{35}$ Burrington, supra note 4 , at 728 .

${ }^{36}$ See supra notes 6,9 and accompanying text.
} 
AASHTO guidelines a relevant factor in determining whether government employees have negligently designed a road.

\section{What's Wrong with Speed?}

Transportation agencies' focus on high-speed traffic makes American streets more dangerous in three ways. First, a motorist driving at a high speed is more likely to crash into other travelers such as pedestrians, bicyclists, and other drivers. The Green Book itself concedes that "[s]peed reduces the visual field, restricts peripheral vision, and limits the time available for drivers to receive and process information. ${ }^{37}$ At a speed of thirty miles per hour, a motorist has a 150 -degree field of vision. ${ }^{38}$ At sixty miles per hour, the motorist's field of vision is reduced by two-thirds to fifty degrees. ${ }^{39}$ Consequently, a speeding motorist is less likely to notice pedestrians or bicyclists or, for that matter, other drivers. ${ }^{40}$ Second, even if a speeding motorist notices another traveler, the motorist may not be able to stop in time to avoid a collision. A motorist driving forty miles per hour at the time he notices another traveler will not be able to stop until after he has traveled 120 feet; by contrast, a driver who is traveling at half that speed will be able to stop after she has traveled only forty feet. ${ }^{41}$ Third, if a motorist does collide with another traveler, the crash is more likely to be fatal if the motorist is driving at a high speed. ${ }^{42}$ A pedestrian has a $3.5 \%$ chance of being killed by a vehicle traveling at fifteen miles per hour, but her likelihood of death increases to $37 \%$ when the vehicle is traveling at thirty-one miles per hour and to $83 \%$ when the vehicle is traveling at forty-four miles per hour. ${ }^{43}$

${ }^{37}$ AASHTO 2004, supra note 7, at 56.

${ }^{38}$ See Burrington, supra note 4, at 704 n.50 (citation omitted).

${ }^{39} \mathrm{Id}$.

${ }^{40} \mathrm{Id}$.

${ }^{41}$ See Joey Ledford, The Lane Ranger: Speeding Cars Terrify Neighborhoods, ATLANTA J.ConsT., Aug. 27, 1997, at B, available at 1997 WLNR 3173969 ("At 20 mph, it takes you 20 feet to react [to a pedestrian or vehicle in the street] and another 20 feet to stop. At $40 \mathrm{mph}$, it's 40 feet to think and another 80 feet to stop.").

${ }^{42}$ See AASHTO 2004, supra note 7, at 56 ("[T] he severity of crashes is generally greater with increased speed.").

${ }^{43}$ Burrington, supra note 4, at 704; see also Philip Langdon, Calming Rural Roads, PlanNING, May 1, 2003, at 30 ("In 2001, a Federal Highway Administration report indicated that lowering speed from $40 \mathrm{mph}$ to $30 \mathrm{mph}$ halves the fatality risk. In contrast, an article that appeared in 2000 on the Institute of Transportation Engineers website found that when average speed increases from $20 \mathrm{mph}$ to $30 \mathrm{mph}$, the risk of injury to pedestrians multiplies 7.6 times."); cf. Andres Viglucci, Walk at Your Own Risk in State, Miami Herald, Nov. 21, 2002, at 1B, 
In addition to reducing actual street safety, faster traffic discourages walking and biking because it affects public perceptions of street safety. In 1969 , nearly half of schoolchildren traveled to school on foot or bike, while today only $15 \%$ do so. ${ }^{44}$ According to a study by the Centers for Disease Control, $40 \%$ of parents whose children do not walk to school cited danger from traffic as a reason ${ }^{45}$-about twice the number of parents who cited crime or weather as factors. ${ }^{46}$ Furthermore, when parents drive their children to school, they create traffic congestion. In a county in California, for example, more than $20 \%$ of morning rush-hour traffic is school-related. ${ }^{47}$ Such congestion creates political pressure for even wider roads, ${ }^{48}$ which in turn makes streets more dangerous for pedestrians. ${ }^{49}$

In sum, traffic engineers' emphasis on speed has made American streets more dangerous for pedestrians and bicyclists. ${ }^{50}$ As a result of this danger, short trips that could be made on foot or bike are instead made by motor

available at 2002 WLNR 4612969 (indicating that pedestrian fatalities are most common "along wide suburban arterials with fast-moving traffic" and in the most automobile-oriented cities).

${ }^{44}$ See Catherine Malina \& John M. Balbus, Environmental Interventions to Help Address the Obesity and Asthma Epidemics in Children, 17 DUKE ENVTL. L \& POL'Y F. 193, 195 (2007). ${ }^{45} I$.

${ }^{46}$ See Don Finley, Fear Keeps Kids off Their Feet: Once Terrific Walkers, Schoolchildren Don't Have the Run of the Neighborhood Anymore, SAN ANTONiO EXPRESS-NEWS, Dec. 10, 2002, at 08A, available at 2002 WLNR 13912775 (by contrast, only "24 percent cited weather and 18 percent the fear of crime").

${ }^{47}$ See Bruce S. Appleyard, Planning Safe Routes to School, PLANNING, May 1, 2003, at 34, available at http://www.saferoutestoschools.org/Pressroom/PlanningSRTS.shtml ("In Marin County, California, for example, it is estimated that 21 percent to 27 percent of peak morning traffic is school-related.").

${ }^{48}$ See Burrington, supra note 4, at 701 (congestion caused by fast traffic "results in a need for more and larger roads").

${ }^{49}$ See supra notes 25-27, 37-43 and accompanying text (explaining why wider streets are less safe and less comfortable for pedestrians than narrower roads); Jaskiewicz, supra note 24, at G-1/8 (wider streets encourage fast driving, while narrower streets encourage slower driving).

${ }^{50} \mathrm{Cf}$. infra Part III (suggesting that fast traffic may create dangers for drivers as well). It could be argued that street-design reforms are unnecessary to improve pedestrian safety because even on a street designed for fast traffic, cities could prevent speeding merely by enforcing a speed limit. But as a practical matter, speed limits are frequently ignored on streets and highways designed for high speeds. See David W. Opderbeck, Peer-to-Peer Networks, Technological Evolution, and Intellectual Property Reverse Private Attorney General Litigation, 20 BERKELEY TECH. L.J. 1685, 1709 (2005) ("In many parts of the United States ... highway speed limits are routinely ignored ...."); Allen M. Brabender, The Misapplication of Minnesota's Speeding Statute and the Need to Raise the Posted Limit or Expand Use of the Dimler Amendment, 27 HAMLINE L. REV. 1, 11-12 (2004) (where speed limits are significantly lower than speeds actually traveled by most motorists, such speed limits "are ignored by many drivers and are difficult to enforce"). Thus, speed limit enforcement is unlikely to slow traffic unless cities invest significant resources into monitoring traffic on every major street. 
vehicles, which intensifies congestion on the road and air pollution that results from the increased use of vehicles. ${ }^{51}$

\section{The Street Reform Movement}

In 1991, the Intermodal Surface Transportation Efficiency Act (ISTEA) deregulated street design when it allowed states to use non-AASHTO guidelines on most road projects. $^{52}$ The National Highway System Act of 1995 provided transportation planners additional flexibility because it allowed the design of all roads, other than interstate highways, to take into account "environmental, scenic or historic values," 33 notwithstanding AASHTO guidelines. $^{54}$ As a result, federal law no longer requires state and local transportation planners to follow the Green Book except with regard to building interstate highways. 55

After the federal government deregulated street design, a group of transportation planners began to create the "context-sensitive design" (CSD)

${ }^{51}$ See Oliver Gillham, The Limitless Crty: A Primer on the Urban SPRAWl Debate 95, 113-14 (2002) (discussing growth of traffic congestion and hazards of car-induced air pollution).

${ }^{52}$ See 23 U.S.C. $\$ 109$ (o) (2006) ("Projects (other than highway projects on the National Highway System) shall be designed, constructed, operated, and maintained in accordance with State laws, regulations, directives, safety standards, design standards, and construction standards."); Burrington, supra note 4, at 728 (this language, adopted as part of ISTEA, means that "most streets and roads [are] no longer subject to any federal design rules") (quoting statutory language). By contrast, before ISTEA, all federally funded projects were governed by the Green Book - a category that was not confined to limited-access highways, but in fact included a wide variety of streets. Id. ("most streets and roads" are federally funded and thus affected by ISTEA); Lorick Associates Consulting, Sonoma CounTy PUblic Works MANAGEMENT \& SYSTEMS REVIEw: FinAL REPORT at 1-2 (2007), http://www.sonomacounty.org/tpw/pdf/tpw_assessment_final_report.pdf [hereinafter SONOMA COUNTY REPORT] (In Sonoma County, California, " $23 \%$ of roads are federally funded arterial roads, $15 \%$ of roads are federally funded residential/local roads and $13 \%$ of roads are federally funded collector roads."); see also infra notes 85-91 and accompanying text (explaining concepts of "arterial" and "collector" roads).

${ }^{53} 23$ U.S.C. $\$ 109(\mathrm{p})(1)(2006)$.

${ }^{54}$ See Burrington, supra note 4, at 730-31 (describing 1995 legislation and its impact upon use of AASHTO guidelines).

${ }^{55}$ Id. at 731 (1995 legislation "did away with the last remaining federal statutory basis for following the AASHTO guidelines"). To the extent a state's road design guidelines are similar to those of the Green Book, the discussion below is applicable to those guidelines. Cf. Ewing, supra note 34 (discussing some states' rules); FLA. DEP'T OF TRANSPORTATION, MANUAL OF UNIFORM MINIMUM STANDARDS FOR DESIGN, CONSTRUCTION AND MAINTENANCE FOR STREETS AND HIGHWAYS (2005), http://www.dot.state.fl.us/rddesign/FloridaGreenbook/2005/ 2005FloridaGreenbook.pdf (an example of one state's guidelines). 
movement. ${ }^{56}$ The CSD movement seeks to take account of a street's historic and economic context before designing the street. ${ }^{57}$ As a practical matter, then, the CSD movement encourages transportation engineers to consider the needs of pedestrians and bicyclists ${ }^{58}$ as well as the needs of drivers. ${ }^{59}$ For example, the CSD movement might encourage narrower streets in a historic downtown than on a limited-access highway. ${ }^{60}$

Traffic engineering organizations are beginning to amend their guidelines to reflect the growth of the CSD movement. In 2006, the Institute of Transportation Engineers (ITE), an organization of private consultants and government transportation planners, ${ }^{61}$ published guidelines on "contextsensitive solutions ${ }^{\prime 62}$ with assistance from the Federal Highway Administration and the Environmental Protection Agency. ${ }^{63}$ The ITE Manual proposes that

${ }^{56}$ See Editorial, The Right Road, HARTFORD COURANT, July 15, 2007, at Cl, available at 2007 WLNR 13546079 ("In the 1990s, there was a movement across the country to better blend road design into communities ... . which in planning jargon is called 'context-sensitive design.'"); infra note 62 and accompanying text (the Institute of Transportation Engineers, a group that has issued a CSD manual, is comprised of planners, consultants, and transportation engineers).

${ }^{57}$ See Toni Gold, New Road Policy Means More Than Pavement, HaRTFORd Courant, Apr. 16, 2006, at C5, available at 2006 WLNR 7279203 (CSD "recognizes and is sensitive to the context beyond the pavement, be it historic, natural, scenic or economic").

58 As opposed to limited-access roads such as expressways. See INSTITUTE OF Transportation Engineers, Context-Sensitive Solutions in Designing Major Urban THOROUGHFARES FOR WALKABLE COMMUNITIES 3 (2006), http://www.ite.org/ bookstore/RP036.pdf [hereinafter ITE MANUAL] (context-sensitive design guidelines in manual "exclude high-speed limited access facilities").

${ }^{59}$ See Editorial, supra note 56 (CSD seeks "to balance the needs of vehicle movement with those of pedestrians, bicyclists, bus riders, shop owners and others."); Brian S. Bochner, Beyond the Current Envelope-Context-Sensitive Street Design, 74 InST. Transp. ENG'RS J. 28 (2004), available at 2004 WLNR 11538347 ("Context-sensitive design serves a variety of usersincluding drivers, pedestrians, bicyclists, the aged and the handicapped and a variety of travel modes-including personal vehicles, trucks, emergency vehicles, bicycles and walking.").

${ }^{60} \mathrm{Cf}$. Steve Chambers, Just Around the Bend: A New Look at Roads, THE STAR-LEDGER, Nov. 3, 2003, at 13, available at 2003 WLNR 15643704 (one example of CSD was a small New Jersey town's decision to reduce its downtown main street from four lanes to two, "making it less a speedway and more a thoroughfare of a sleepy downtown").

${ }^{61}$ ITE's membership includes private-sector consultants and planners as well as government-employed transportation planners. ITE thus tends to be "more receptive to changing entrenched practices than most of the highway-building establishment." See Ehrenhalt, supra note 9.

${ }^{62}$ This term is synonymous with CSD. See ITE MANUAL, supra note 58, at 3 (using terms "context-sensitive design" and "context-sensitive solutions" interchangeably).

${ }^{63} I d$. at ix (listing sponsors). 
street networks should "make walking, transit and bicycle travel efficient and enjoyable." ${ }^{64}$

While the Green Book seeks to provide guidelines for a wide variety of streets, ${ }^{65}$ the ITE Manual seeks only to provide guidance on street design "in places where the qualities of walkable communities are a high priority objective." ${ }^{.66}$ Thus, the ITE Manual's goals are more limited than those of the Green Book.

In response to the CSD movement, AASHTO has also begun to consider the interests of pedestrians and other non-drivers. In 2004, AASHTO published its most recent edition of the Green Book. ${ }^{67}$ In its foreword, the 2004 Green Book states: "Emphasis has been placed on the joint use of transportation corridors by pedestrians, cyclists and public transit vehicles. Designers should recognize the implications of this sharing of the transportation corridors and are encouraged to consider not only vehicular movement, but also movement of people [and of goods and services]. ${ }^{, 68}$

In particular, the Green Book states that in designing "local" urban streets-that is, those serving pedestrians "primarily to provide access to adjacent residential development areas" $\rightarrow$ a street-builder's "overriding consideration is to foster a safe and pleasant environment whereas the convenience of the motorist is secondary." ${ }^{, 70}$ To protect pedestrians, the Green Book recommends sidewalks even in rural and suburban areas, ${ }^{71}$ whether those areas are residential ${ }^{72}$ or commercial. ${ }^{73}$ The Green Book's section on

${ }^{64}$ Id. at 10.

${ }^{65}$ See Burrington, supra note 4, at 728 (until 1991, all federally funded road projects had to comply with Green Book guidelines); see also SONOMA COUNTY REPORT, supra note 52 (a wide variety of roads are federally funded).

${ }^{66}$ ITE MANUAL, supra note 58, at 10 . Some states have also endorsed context-sensitive design. See, e.g., Mass. Highway Dep'T, Project DeVelopment \& Design Guide 1-4 (2006), http://www.vhb.com/mhdGuide/mhd_GuideBook.asp.

${ }^{67}$ See generally AASHTO 2004, supra note 7.

${ }^{68}$ Id. at xliv.

${ }^{69}$ Id. at 390.

${ }^{70}$ Id.

${ }^{71}$ Id. at 358 ("As a general practice, sidewalks should be constructed along any street or highway not provided with shoulders, even though pedestrian traffic may be light.") (emphasis added); id. at 357 ("[S]idewalks in rural areas do reduce pedestrian collisions."); id. at 357 (sidewalks are "often justified" in rural and suburban areas wherever there are "residential areas, schools, local businesses, and industrial plants, that result in pedestrian concentrations").

${ }^{72}$ Id. at 357 ("When suburban residential areas are developed, initial roadway facilities are needed for the development to function, but the construction of sidewalks is sometimes deferred. However, if pedestrian activity is anticipated, sidewalks should be included as part of the 
pedestrian movements even concedes that wide streets create problems for pedestrians, stating: "The wider the street, the longer it takes a pedestrian to cross." 74

The Green Book's street-width rules have also evolved. For example, the Green Book no longer favors the creation of six- and eight-lane streets. ${ }^{75}$ Even on arterial streets - the most heavily trafficked, high-speed streets ${ }^{76}$ - the Green Book now describes four-lane streets as "normal" and recommends that transportation planners build medians in order to protect pedestrians from heavy traffic on such streets. ${ }^{78}$ According to the most recent version of the Green Book, intermediate-scale "collector" streets ${ }^{79}$ require only two lanes of moving traffic, ${ }^{80}$ and smaller local streets require only one or two lanes. ${ }^{81}$ Although the Green Book suggests that twelve-foot lanes are desirable under certain circumstances, ${ }^{82}$ it allows lanes as narrow as nine feet on collector streets ${ }^{83}$ and eleven feet on arterial streets. ${ }^{84}$ Thus, the Green Book no longer forecloses the creation of low-speed, pedestrian-friendly streets.

construction."); $i d$. at 398 ("In residential areas, sidewalks should be provided on at least one side of all local streets and are desirable on both sides of the street."); id. at 436 ("In residential areas, sidewalks are desirable on both sides of collector streets, but should be provided on at least one side.").

${ }^{73}$ Id. ("Sidewalks should be provided . . along all collectors in commercial areas.") (emphasis added).

${ }^{74}$ Id. at 99.

${ }^{75}$ Cf. Lewyn, supra note 23, and accompanying text (describing 1950s AASHTO manual encouraging the construction of such streets).

${ }^{76}$ See AASHTO 2004, supra note 7, at 469 ("Urban arterials carry large traffic volumes within and through urban areas."); id. at 10-12 (comparing arterials to lower-speed "collector" streets and even slower "local" streets).

${ }^{77} I d$. at 473 ("[T]he normal range for urban arterial streets is four to eight lanes.").

${ }^{78}$ Id. at 474 (medians "desirable" on arterial streets). The widest collector streets should also have medians. Id. at 434 ("Urban collector streets designed for four or more lanes should include width for an appropriate median treatment, where practical.").

${ }^{79}$ Id. at 419 ("The collector has aspects of both arterials and local roads and often serves as a connection between them .... usually serving moderate traffic volumes.").

${ }^{80}$ Id. at 433 ("Two moving lanes plus additional width for shoulders and parking are sufficient for most urban collector streets.").

${ }^{81}$ Id. at 392 (Where parking is allowed on both sides of a residential street, only "one unobstructed moving lane must be ensured"; however, "[i]n multifamily residential areas, a minimum of two moving traffic lanes to accommodate opposing traffic may be desirable.").

${ }^{82}$ Id. at 311 (twelve-foot lanes desirable on two-lane, two-way rural highways "when high traffic volumes and particularly high percentages of commercial vehicles are expected").

${ }^{83} I d$. ("Lane widths of 2.7 to $3.6 \mathrm{~m}$ [9 to $12 \mathrm{ft}$ ] are generally used....").

${ }^{84} \mathrm{ld}$. at 472 ("Lane widths of $3.3 \mathrm{~m}$ [ $11 \mathrm{ft}$ ] are used quite extensively for urban arterial street designs." Even ten-foot lanes may be appropriate on arterials, but only in "areas having little or no truck traffic."). 


\section{Not Enough Evolution}

The Green Book, however, continues to disfavor pedestrians in some important respects. The Green Book creates a hierarchy of streets: ${ }^{85}$ freeways and arterials should be the widest streets ${ }^{86}$ with the heaviest traffic; ${ }^{87}$ vehicles then exit freeways and arterial streets to enter collector streets that penetrate neighborhoods ${ }^{88}$ and then exit the collector streets to enter quieter, local streets. ${ }^{89}$ The Green Book states that the collector-street system "collects traffic from local streets in residential neighborhoods and channels it into the arterial system, ${ }^{, 90}$ which implies that local streets are purely residential and that streets with other land uses should be collectors and arterials. Residential streets, as a result, "feed broad connector streets, which, in turn, feed busy multilane arterials." $" 91$

This street hierarchy creates a subtle bias in favor of separating housing from commerce: if the busiest streets are typically arterials, major commercial streets, as the busiest streets, will thus be arterials. ${ }^{92}$ Because commercial streets (a) are usually arterial and (b) usually intersect with collector streets, a resident of a local street, therefore, might have to walk across two types of streets-his own local street and a collector street-to reach a shop or job located on an arterial street. It follows that transportation planners who adopt the Green Book's hierarchical street design may increase the distance between housing and commerce, which discourages people from walking from their homes to jobs and shops. ${ }^{93}$

${ }^{85}$ Id. at 1 (using the term "movement hierarchy" to describe types of streets, ranging from highest volume streets to lowest volume streets).

${ }^{86}$ See supra notes $76-81$ and accompanying text.

${ }^{87}$ See AASHTO 2004, supra note 7, at 11 (urban arterial system serves "the highest traffic volume corridors").

${ }^{88}$ Id. at 419 ("Collector streets link neighborhoods ... with the arterial street system," thus serving "traffic movements between arterials and local streets.").

${ }^{89} I d$. at 1 .

${ }^{90} \mathrm{Id}$. at 12.

${ }^{91}$ Editorial, Neighborhoods Reborn, CONSUMER REPORTS, May 1, 1996, at 25, available at 1996 WLNR 243157.

${ }^{92}$ I note that arterial streets are generally not limited-access freeways. Rather, the Green Book contemplates that arterials will include commercial or residential development. See, e.g., AASHTO 2004, supra note 7, at 469 ("Development along an arterial should be anticipated regardless of a city's size.").

${ }^{93} \mathrm{Cf}$. ITE MANUAL, supra note 58 , at 11 (noting that communities are more walkable if "[m]ixed land uses [are] in close proximity to one another"). 
The Green Book also continues to encourage high-speed driving in a variety of ways. By favoring high speeds on commercial, collector, and arterial streets, the Green Book causes businesses to be placed on high-speed streets. The Green Book states that the design speed ${ }^{94}$ for urban arterials should be thirty to sixty miles per hour ${ }^{95}$ and similarly states that "a design speed of 50 $\mathrm{km} / \mathrm{h}[30 \mathrm{mph}]$ or higher should be used for urban collector streets, ${ }^{, 96}$ thereby implying that cars should move almost as rapidly on collector streets as on arterials.

Moreover, a variety of other Green Book provisions encourage road designers to err on the high end of acceptable design-speed ranges: that is, to build streets that accommodate sixty-mile-per-hour traffic rather than thirtymile-per-hour traffic. The Green Book states that as a general matter, streets should "be designed to operate at a speed that satisfies nearly all drivers,",97 though presumably not all pedestrians or bicyclists, and that "every effort should be made to use as high a design speed as practical." ${ }^{\text {98 }}$

One factor used in determining appropriate street design is likely traffic volume. According to the Green Book, high-traffic streets should be designed for higher speeds, and roads with less traffic should be designed for lower speeds. ${ }^{99}$ For example, a high-traffic collector street should be wider than a low-traffic collector, regardless of its classification as local, collector, or arterial. ${ }^{100}$ Accordingly, the busiest streets will typically be the widest, which increases the risk that streets with large numbers of jobs and shops will be too wide for pedestrians to use with safety and comfort.

${ }^{94}$ Design speed is the "speed used to design the various geometric design features of the roadway." AASHTO 2004, supra note 7, at 67.

${ }^{95} \mathrm{Id}$. at 470 ("Design speeds for urban arterials generally range from 50 to $100 \mathrm{~km} / \mathrm{h}$ [30 to $60 \mathrm{mph].").}$

${ }_{96}$ Id. at 430 (emphasis added).

${ }^{97}$ Id. at 66 .

${ }^{98}$ Id. at 67 .

${ }^{99} I d$. at 389-90 (indicating that lower design speeds are appropriate on low-volume residential streets).

${ }^{100} I d$. at 433 (providing that even though two moving traffic lanes are sufficient for most collector streets, the "number of lanes to be provided on urban collector streets with high traffic volumes should be determined from a capacity analysis"). Admittedly, "likely pedestrian presence" is one of the factors that should be used in deciding the appropriate design speed for collectors. Id. at 430 . However, this is just one of a number of relevant factors. Id. (adding that road designers should also consider "available right-of-way, terrain, adjacent development ... and other site controls"). Thus, collectors may be designed for high speeds even if they are used by pedestrians. 
The Green Book does not recommend, however, designing streets for average traffic volumes or even average rush-hour traffic volumes, because such design would be inadequate to handle rush-hour traffic on the days when congestion is at its highest. ${ }^{101}$ The Green Book instead advocates that roads should be designed for "the 30th highest hourly volume of the year."102 Because each year is made up of 8760 hours, ${ }^{103}$ roads will reach this hourlyvolume rule less than one half of one percent of the time. This "thirty-hour rule" is not based on existing traffic volumes, but on "traffic volumes for a 20year design period." 104 Consequently, if transportation planners conclude that a road is likely to become crowded over time, they can design it to accommodate more traffic than the road will have for decades. The Green Book, then, effectively recommends designing roads large enough to handle the worst-case scenario twenty years after the road's construction. If highway planners determine that an eight-lane road is necessary to handle rush-hour traffic on the busiest days in 2028, they will build the eight-lane road even if a narrower road is presently adequate or will be adequate for years in the future. ${ }^{105}$

The Green Book also continues to disfavor the creation of on-street parking on arterial streets, ${ }^{106}$ even though on-street parking may well reduce the potential for pedestrian-vehicle collisions. On-street parking creates a buffer zone between moving vehicles and pedestrians, which may effectively reduce pedestrian fatalities. ${ }^{107}$ If a pedestrian must cross a four-lane street without onstreet parking, she must walk through four lanes of traffic.

The Green Book states that " $[\mathrm{z}]$ oning regulations should require ample offstreet parking as a condition for approval of a building permit" to build near arterial streets. ${ }^{108}$ Where parking is off-street, buildings are typically surrounded by parking lots, ${ }^{109}$ which in turn means that pedestrians have longer

${ }^{101}$ Id. at 59.

${ }^{102}$ Id.

${ }^{103}$ Twenty-four (the number of hours in a day) multiplied by 365 (the number of days in a year) equals 8760 .

${ }^{104}$ AASHTO 2004, supra note 7, at 65.

${ }^{105}$ See, e.g., Conservation Law Found. v. Fed. Highway Admin., No. 06-CV-45-PB, 2007 WL 2492737 , at $* 27$ (D.N.H. Aug. 30, 2007) (allowing government to widen a road from two lanes in each direction to four lanes in each direction, based on projections of 2020 traffic).

${ }^{106}$ AASHTO 2004, supra note 7, at 373 (asserting that on-street parking "decreases through-traffic capacity, impedes traffic flow, and increases crash potential").

${ }^{107}$ See Jaskiewicz, supra note 24.

${ }^{108}$ AASHTO 2004, supra note 7, at 483.

${ }^{109}$ This is assuming, of course, that such parking is aboveground. It could be argued that rather than encouraging on-street parking, governments should require landowners to install underground parking because such parking does not inconvenience pedestrians as much as 
and more dangerous trips to those buildings than they otherwise might. To reach a shop or job surrounded by parking lots, pedestrians must not only cross streets, but must also cross through the parking lot and dodge vehicles traveling through that parking lot. ${ }^{110}$

The Green Book's insistence on off-street parking effectively widens streets and increases pedestrian exposure to auto traffic in two ways: (1) it advocates the removal of on-street parking that protects pedestrians from fast-moving cars, and (2) it forces landowners and business owners to create off-street parking lots that separate pedestrians from their destinations. ${ }^{111}$

aboveground parking lots and does not endanger bicyclists as much as on-street parking. However, underground parking is more costly than aboveground parking, and thus it is unlikely to be adopted everywhere unless a government wishes to impose the additional costs of building parking lots underground upon landowners-costs which in turn may be passed on to the rest of society in the form of higher prices for goods and services. See DONALD C. SHOUP, THE HIGH COST OF FREE PARKING 2, 148-51 (2005) (pointing out that landowners may pass costs of parking lot construction on to consumers, and citing examples of housing developments in which parking increased construction costs by more than thirty percent); Nancy Samoff \& David Kaplan, This Luxury Is for Display Purposes Only: Full-Scale Models Aim to Sell Condos Before They've Even Been Built, Houston CHRON., Aug. 26, 2007, at 3, available at 2007 WLNR 16663162 (quoting developer's assertion that underground parking makes mixeduse developments more costly than other forms of development).

${ }^{110}$ See Lewyn, supra note 23, at 280.

${ }^{111}$ On the other hand, it could be argued that on-street parking decreases bicyclist safety because when a driver opens the door of a parked car there is some risk that a bicyclist could crash into that door. See Dennis Hoey, Cape's Town Center Plan Moves Forward: The Planning Board Endorses a Strict Set of Zoning Rules for the Pond Cove Commercial District, PORTLAND PRESS HERALD, Oct. 24, 1994, at 1B, available at 1994 WLNR 4001992 (noting that "drivers opening doors present a hazard to bicyclists"); WAYNE PEIN, BICYCLING AND ONSTREet Parallel PaRKING 1 (2003), available at http://www.humantransport.org/ bicycledriving/library/door_zone.pdf (discussing the problem that open doors might injure bicyclists). However, this problem can be resolved by installing markings that communicate the location of "door zones" (that is, areas within a door's width of parked vehicles), thus encouraging bicyclists to avoid those zones. Id. at 1,3 . Alternatively, on-street parking could be diagonal rather than horizontal, thus eliminating the risk of "dooring"; even though bicyclists might face a risk of colliding with cars pulling in and out of diagonal parking spaces, those cars might move more slowly than an opening door. Id. at 1 . Finally, bicycle lanes could be installed on the left side of streets, far away from off-street parking. In any event, the harm caused by dooring may well be outweighed by the danger to bicyclists from increased automobile speeds in the absence of off-street parking; by narrowing streets, on-street parking effectively slows traffic, reducing the risk of a major accident. See supra notes 37-43 and accompanying text (discussing dangers of high-speed traffic); Cindy Larson, A Return to OldFashioned Neighborhoods: Carmel Joins Housing with Commercial District, FORT WAYNE NEWS SENTINEL, Dec. 30, 2003, at 1A, available at 2003 WLNR 14401372 (indicating that onstreet parking "serves to slow down traffic, making the neighborhood more conducive to walking and biking"); IOWA DeP'T OF TranSPORTATION, ANGLE PARKING ON IOWA's Low Volume Primary EXTENSIONS IN SMALl TOWNS: FINAL REPORT 9 (2003), available at 
Government-mandated off-street parking impairs pedestrian comfort as well as pedestrian safety. The "strip mall landscapes" created by parking lots are as aesthetically unappealing as they are inconvenient: off-street parking in front of buildings restricts a pedestrian's immediate view to the parking lot only. ${ }^{112}$ By contrast, on-street parking allows sidewalks to border storefronts and other land uses more visually appealing than parking lots. ${ }^{113}$

Because land devoted to parking cannot be devoted to housing or businesses, off-street parking artificially disperses traditionally populated areas. For example, in 1961, Oakland, California, began to require apartment buildings to provide parking spaces for their tenants. ${ }^{114}$ Within three years, the number of apartments per acre in Oakland fell by thirty percent. ${ }^{115}$ Government-mandated low-density areas result in fewer residences and businesses per acre, which in turn means that fewer of these destinations can be placed within a short walk of each other. ${ }^{116}$ In other words, by reducing population density, off-street parking also reduces walkability.

The Green Book also disfavors street trees, ${ }^{117}$ stating that even on collector streets, "obstacles, such as trees, that might seriously damage out-of-control vehicles should be removed wherever practical." " Street trees, however, may actually enhance safety for both drivers and pedestrians by giving drivers the

http://publications.iowa.gov/archive/00002630/01/angle_parking_safety.pdf("[W]hen average crash rates for various parking types were compared," it was observed that rates for areas with diagonal and parallel on-street parking "were less than sample locations with no parking at all."). But see id. at 2 (noting studies on both sides of issue).

${ }^{112}$ See Lewyn, supra note 23, at 280.

${ }^{113} \mathrm{Id}$.

${ }^{114}$ SHOUP, supra note 109 , at 143.

${ }^{115} I d$. at 143-44.

${ }^{116}$ See Katharine B. Silbaugh, Wal-Mart's Other Woman Problem: Sprawl and WorkFamily Balance, 39 CoNN. L. REv. 1713, 1717 (2007) ("Pedestrians can be found in places where density and mixed-use zoning create short trips."); Maureen Klovers, The Nexus Between Sprawl, Neighborhood Effects and Urban Crime, 11 GEO. PUB. PoL'Y L. REv. 35, 42 (2006) (only "densities above 3500 [persons per square mile] are sufficient to support public transportation, small retail, and pedestrian traffic").

117 "Street trees" are trees planted between streets and sidewalks. See Ruthmarie Shea, Whose Tree Is It Anyway? A Case of First Impression, 77 U. DET. MERCY L. REV. 579, 580 (2000).

${ }^{118}$ AASHTO 2004, supra note 7, at 437; see also id. at 481 (recommending that urban arterials be "clear" of obstructions). On the other hand, the Green Book states that "the potential benefits of removing such obstacles should be weighed against the adverse environmental and aesthetic effects of their removal. Therefore, trees should be removed only when considered essential for safety." Id. at 437. This statement means that not all existing street trees need be removed; however, the Green Book certainly does not encourage cities to plant any new street trees. As such, the Green Book seems to favor reduction of street trees. 
impression that a street has a defined edge, ${ }^{119}$ which could slow traffic and reduce the number and severity of accidents. ${ }^{120}$ Street trees also make walking more comfortable by protecting pedestrians from sun and rain. ${ }^{121}$

In sum, the Green Book still encourages the creation of high-speed streets that are uncomfortable and unsafe for pedestrians, both through its specific recommendations and its overall bias in favor of high-speed traffic. It is important to note, though, that the Green Book's most anti-pedestrian provisions do not set forth mandatory rules that bind transportation planners. The foreword in the most recent version of the Green Book states that it is "not intended to be a detailed design manual that could super[s]ede the need for the application of sound principles by the knowledgeable design professional. Sufficient flexibility is permitted to encourage independent designs tailored to particular situations." 122

\section{B. Tort Law and Traffic: The Rise and Fall of Sovereign Immunity}

At British common law, the government could not be sued because "the king was considered immune from suit in his own courts absent his consent." 23 American courts adopted a similar view, ${ }^{124}$ but in the second half of the twentieth century, states became more willing to subject themselves and their municipalities to suit. ${ }^{125}$ Today, only three states retain traditional sovereign

119 Dan BURden, 22 Benefits of URBan StReEt TREes 4 (2006), available at http://www.ufei.org/files/pubs/22BenefitsofUrbanStreetTrees.pdf.

${ }^{120} \mathrm{Id}$. at 4,13 (noting that street trees reduce motorist speed).

${ }^{121}$ Id. at 5,11 .

${ }^{122}$ AASHTO 2004, supra note 7, at xliii.

${ }^{123}$ James F. Caputo, Note, Copy-Katz: Sovereign Immunity, the Intellectual Property Clause, and Central Virginia Community College v. Katz, 95 GEO. L.J. 1911, 1914 (2007).

${ }^{124}$ See Debra L. Stephens \& Bryan P. Harnetiaux, The Value of Government Tort Liability: Washington State's Journey From Immunity to Accountability, 30 SEATTLE U. L. REV. 35, 37 (2006) ("From the formation of the United States, both the federal government and the several states adopted the notion of sovereign immunity that had prevailed in England since ancient times."); DAN B. DOBBS, THE LAW OF TORTS $\S 269$ (2000) (noting that municipalities are also generally immune from tort suit at common law).

${ }^{125}$ See Margaret R. Solis, Note, Municipal Law-How Broad a Remedy? Municipal Liability and the Massachusetts Civil Rights Act, 29 W. New ENG. L. REv. 841, 871 (2007) ("During the 1960 s and 1970 s, a number of states modified their common law rules of sovereign immunity to allow suits against municipalities, the state, or both."). 
immunity. ${ }^{126}$ With the decline of sovereign immunity in recent decades, claims against state and local transportation agencies have increased. ${ }^{127}$

As a rule, transportation agencies owe a duty to the public to maintain roads and streets in a reasonably safe condition. ${ }^{128}$ Injured motorists will often claim that roads not in compliance with AASHTO guidelines are not "reasonably safe" and that transportation agencies that build and maintain those roads are negligent. ${ }^{129}$ Thus, government agencies have had strong incentive to conform to AASHTO guidelines as a way to avoid tort liability.

In Hussey v. Russell, ${ }^{130}$ numerous drivers and passengers were injured in a two-car collision and subsequently sued the state department of transportation for negligent street design. ${ }^{131}$ The plaintiffs' expert concluded that the state's failure to follow AASHTO guidelines was a contributing cause of the accident. He explained that according to AASHTO maintenance manuals, road shoulders near curves should be reinforced with additional paving to prevent motorists from veering off the pavement. ${ }^{132}$ After discussing other expert testimony unrelated to AASHTO guidelines, ${ }^{133}$ a Louisiana appellate court held that "there was a reasonable basis upon which the trial court could have found fault on the part of [the Louisiana Department of Transportation and Development]." ${ }^{134}$ Hussey supports the view that a government agency that deviates from AASHTO guidelines is, all other factors being equal, more likely to be held negligent.

${ }^{126}$ See DoBBS, supra note $124, \S 268$, at $716 \&$ n. 7 (stating that only Alabama, South Dakota, and Wisconsin prohibit suits against the state).

${ }^{127}$ See JAY L. SMITH ET AL., TRANSP. RESEARCh BD., TRANSPORTATION TORT LAW: A LOOK FORWARD 1, available at http://onlinepubs.trb.org/onlinepubs/millennium/00133.pdf(“'[S]tate and local transportation agencies are experiencing a dramatic increase in tort litigation involving claims for personal injury and property damage .... The single greatest reason for the explosion of claims against state and local transportation agencies over the last 50 years has been the abolition of the doctrine of sovereign immunity by most states.").

${ }^{128}$ Id. at 2.

${ }^{129}$ Id. (even though governments lack "resources to immediately bring all older roads and bridges up to current AASHTO guidelines[,] [t] he issue of AASHTO guidelines . . . is raised often by plaintiff attorneys in an effort to establish negligence on the part of transportation departments").

${ }^{130} 934$ So. $2 d$ 766, 768 (La. Ct. App. 2006).

${ }^{131}$ Id.

132 Id. at 773.

${ }^{133}$ Id. at 774 (same witness criticized the road's "undulating" curve, which made driving more difficult, as well as the road's high "shoulder drop-off"); id. at 773 (citing another witness's testimony that the road suffered from "puddling of water" and "uneven surface" as well as factors cited by the first witness).

${ }^{134}$ Id. at 775. 
In theory, the growth of tort liability for negligent road design could have justified making streets more pedestrian-friendly. For instance, if governments were worried about pedestrians bringing suit when high-speed traffic caused a car to injure a pedestrian, policy decisions might weigh in favor of creating more pedestrian-friendly streets. ${ }^{135}$ But transportation planners who build highspeed streets are often acting in compliance with AASHTO guidelines, and as a result are unlikely to be found negligent. ${ }^{136}$ By contrast, a planner who builds a more pedestrian-friendly street than the Green Book recommends may face a lawsuit when a speeding motorist is injured on a street designed for low-speed traffic. For example, the motorist might argue that, pursuant to the Green Book, the street should have been wider and that if the street had been wider he would not have been injured. ${ }^{137}$

\section{ANALYSIS: DOES TORT LAW REALLY MANDATE HIGH-SPEED STREET DESIGN?}

Transportation planners follow AASHTO guidelines-at least in part-to avoid the following "nightmare scenario": a planner ignores AASHTO guidelines when she allows on-street parking to create a buffer zone between pedestrians and moving cars. ${ }^{138}$ A motorist crashes into a parked car and sues the government, alleging that the government's failure to widen the street or remove on-street parking negligently caused the collision. The court finds for the driver, holding that the government's noncompliance with AASHTO guidelines is evidence of negligence. This concern, however, does not justify the creation of streets that are unsafe or uncomfortable for pedestrians, for two reasons. First, governments are often immune from tort liability for street design under the "discretionary function" doctrine. Second, AASHTO guidelines provide street designers with considerable flexibility.

135 See supra notes $37-43$ and accompanying text (explaining why high speeds are dangerous for pedestrians).

${ }^{136}$ See supra notes $23-24,31-33,94-105$ and accompanying text (showing how the Green Book has historically encouraged highway planners to design streets that encourage fast driving). width).

${ }^{137}$ See infra notes 144-45, 151-53 and accompanying text (citing cases involving street

${ }^{138}$ See supra note 24 (explaining the benefits of on-street parking). 


\section{A. Discretionary Function Immunity}

In the majority of states, governments are at least partially immune from liability for highway design because governments are generally not liable for negligent decisions arising from "discretionary" government activities, and policy decisions concerning street design are considered discretionary. ${ }^{139}$

The creation of narrow, pedestrian-oriented streets is a "discretionary" decision immune from tort liability for the following three reasons: (1) courts

${ }^{139}$ See Miller v. Nebraska, 302 N.W.2d 692, 694 (Neb. 1981) (Boslaugh, J., concurring), overruled on other grounds by Blitzkie v. Nebraska, 422 N.W.2d 773, 774 (Neb. 1988) ("[T]he majority of the cases which have considered this issue support a rule that, generally, highway design involves a discretionary function."). An American Law Reports annotation cites decisions from over a dozen states in support of this proposition, and this list is by no means exhaustive. See Don F. Vaccaro, Annotation, Liability of Governmental Entity or Public Officer for Personal Injury or Damages Arising out of Vehicular Accident Due to Negligent or Defective Design of a Highway, 45 A.L.R.3d 875, 885-87 (1972) (citing cases from Connecticut, Georgia, Idaho, Iowa, Kansas, Kentucky, Maryland, Minnesota, Missouri, Nebraska, New Jersey, North Carolina, and Tennessee); id. at 90-92 (Supp. 2007) (citing cases from numerous other states); Taylor v. Shoemaker, 605 So. 2d 828, 831-33 (Ala. 1992) (discretionary function immunity protects individual government employees as well as those of government as a whole); Medina v. State, 35 P.3d 443, 456 (Colo. 2001) (Colorado law waives sovereign immunity for failure to maintain roads in existing conditions, but "does not waive immunity in an action to recover for injuries solely attributable to design"); Greenwood v. Easton, 828 N.E.2d 945, 949 n.6 (Mass. 2005) (highway design is a discretionary function); Valescu v. Cleveland Metroparks Sys., 630 N.E.2d 1, 4 (Ohio Ct. App. 1993) ("[T] the road itself is a planning function of the political subdivision, entitling the subdivision to immunity as to liability arising from the design." (citation omitted)); Mann v. McCullough, 26 P.3d 856, 859 (Or. Ct. App. 2001) (stating that although not all design decisions are immune, such decisions are "discretionary" and thus immune when "room for policy judgment" is involved); Rendine v. Flanders, No. 80-3334, 1986 WL 714227, at *2 (R.I. Super. June 3, 1986) (highway "planning and design" discretionary and thus immune from liability); Wulf v. Senst, 669 N.W.2d 135, 143 (S.D. 2003) ("sovereign immunity applies to design of a highway" (citation omitted)); Carter v. Chesterfield County Health Comm'n, 527 S.E.2d 783, 786 (Va. 2000) (" $[\mathrm{We}]$ have held that municipalities are immune from tort liability based on allegations of negligence in the design of roads or streets ...." (citations omitted)). Some states have even created blanket statutory immunity for purposeful highway design decisions. See N.M. STAT. ANN. § 41-4-11(B)(1) (West, Westlaw through 2009 First Regular Sess.) (in New Mexico, immunity applies to "a defect in plan or design of any bridge, culvert, highway, roadway, street, alley, sidewalk or parking area"); S.C. CODE ANN. § 15-78-60(15) (2005) (in South Carolina, governments "are not liable for the design of highways and other public ways"); VT. STAT. ANN. tit. 12, §5601(e)(8) (2002) (in Vermont, immunity is not waived for "claim arising from the selection of or purposeful deviation from a particular set of standards for the planning and design of highways"); WYo. STAT. ANN. § 1-39-120(a)(i) (2007) (Wyoming's waiver of sovereign immunity does not extend to "defect in the plan or design of any bridge, culvert, highway, roadway, street, alley, sidewalk or parking area."). 
have held that broad policy decisions-such as a decision to emphasize pedestrian safety at the expense of vehicle speed-are protected under discretionary immunity, ${ }^{140}$ (2) case law supports the proposition that a government's decision to allow pro-pedestrian street features such as on-street parking and narrower streets is discretionary in nature; ${ }^{141}(3)$ courts may rely on ITE guidelines to support the view that transportation planners may reasonably adopt pro-pedestrian features. ${ }^{142}$ Each of these reasons will be addressed below.

\section{The "Broad Policy Factors" Test}

As a general matter, a government decision is "discretionary" only when "broad policy factors were involved in reaching the allegedly negligent decision." 143 Such "broad policy factors" are clearly present where a government official is consciously choosing to design streets that are slower but safer for pedestrians and bicyclists: the official is weighing the policy of protecting non-drivers' safety against the policy of facilitating fast driving. Consequently, government decisions motivated by the goal of protecting nondrivers from speeding traffic should be treated as discretionary and immune from liability.

\section{Relevant Case Law}

Cases applying the discretionary function doctrine have repeatedly allowed government officials to design narrower or more pedestrian-oriented streets. In Mitchell v. State ${ }^{144}$ the plaintiff was injured in a car crash and claimed the collision was the result of defective road design. A New York appellate court held that "[t]here was no showing that the road could not be traversed safely at its 35-mile-per-hour speed limit ... Cook Road was generally in good condition, despite its narrowness." ${ }^{145}$ Mitchell stands for the proposition that a

${ }^{140}$ See infra Part II.A.1.

${ }^{141}$ See infra Part II.A.2.

142 See infra Part II.A.3.

${ }^{143}$ Breed v. Shaner, 562 P.2d 436, 443 (Haw. 1977) (for example, there is no immunity when an official places a curve in the road to "simply get around an obstacle" rather than to satisfy broader policy goals); see also Estate of Thomas v. La. Dep't of Transp., 604 So. 2d 617, 625 (La. Ct. App. 1992) (immunity applies if challenged decision is "rooted in social, economic or political policy"); Stewart v. State, 597 P.2d 101, 106 (Wash. 1979) (immunity applies if a "policy decision, consciously balancing risks and advantages, took place").

144486 N.Y.S.2d 97 (N.Y. App. Div. 1985).

${ }^{145}$ Id. at 99 (emphasis added). 
road can be safely designed even if it is "narrow" and fit only for a speed limit of thirty-five miles per hour.

It could be argued that a governmental decision to set a low speed limit may itself be negligent because governments have a duty to make roads safe for fast drivers. A California court rejected this argument, however, in Fuller $v$. Department of Transportation. ${ }^{146}$ In Fuller, the court held that the setting of a speed limit was subject to discretionary immunity because "“[d]esign speed,' such as the safe speed at which a curve may be negotiated, is an inherent part of roadway design. The speeds at which vehicles travel, and speed regulations, are part and parcel of the safety features of a road improvement." related decisions, therefore, are subject to "design immunity analysis." suggesting that "the safe speed at which a curve may be negotiated"149 is discretionary, the court implied that any government decisions related to speed are protected by discretionary immunity. It logically follows that if a city or state decides that a street should be designed for twenty-five-mile-per-hour traffic instead of fifty-mile-per-hour traffic, that decision will be protected by discretionary immunity. ${ }^{150}$

Mitchell is not the only case finding that a narrowly designed government road is reasonably safe for vehicular, pedestrian, and bicyclist traffic. In Stewart v. State, ${ }^{151}$ the Washington Supreme Court held that a road was negligently designed because of inadequate lighting ${ }^{152}$ but added in dicta: "The decisions to build the freeway, to place it in this particular location ... the number of lanes - these elements involve a basic governmental policy, program

146107 Cal. Rptr. 2d 823 (Cal. Ct. App. 2001).

${ }^{147} \mathrm{Id}$. at 827 (footnote omitted).

${ }^{148} \mathrm{Id}$.

${ }^{149} \mathrm{Id}$.

${ }^{150}$ Admittedly, the Fuller court distinguished other California cases finding negligence where roads were allegedly unsafe at existing speed limits. See id. at 829. But in the cases cited, government officials were on notice that the roads in question were dangerously designed. Id. at 828 (in one such case, "there was a triable issue of fact whether the public entity had notice, in the one month of the road's use, that it was in a dangerous condition as designed"). Similarly, in another case cited, "the critical issue was notice of a dangerous condition of the roadway." Id. at 828; see infra note 188 (explaining why "notice" theory of liability does not bar officials from designing slow-traffic streets). And even if speed limits were not a discretionary function, governments would be as likely to be liable for designing dangerously high-speed streets as for designing relatively calm streets. Fuller, 107 Cal. Rptr. $2 \mathrm{~d}$ at 828 (describing a case in which a municipality was liable where the speed limit was sixty-five miles per hour and the street could not be safely navigated at such a high speed).

${ }^{151} 597$ P.2d 101, 106 (Wash. 1979).

${ }^{152}$ Id. 
or objective" and as such are discretionary." 153 Based on the holding in Stewart, government decisions regarding the number of lanes on a street should be regarded as discretionary and immune from liability.

Street width is not the only pedestrian-safety issue insulated from liability through discretionary function immunity. As noted above, on-street parking may make streets safer for pedestrians. ${ }^{154}$ In Sorenson $v$. Manchester, the New Hampshire Supreme Court held that a city's decision to allow on-street parking was protected by discretionary immunity. ${ }^{155}$ The plaintiff's husband in Sorenson was killed when his motorcycle collided with a van that was stopped in the middle of the street while waiting to make a turn. ${ }^{156}$ The plaintiff claimed "the city was negligent in permitting both two-way traffic and parking on [that street], thereby reducing the portion of roadway available for moving traffic to such an extent that it was unsafe for travel."157 In other words, by permitting both two-way traffic and on-street parking, the city allegedly made the road less safe. The court rejected the plaintiff's argument, holding that decisions related to parking regulation "rest on the exercise of judgment and discretion and represent planning and policymaking ... [and thus] fit squarely within the category of discretionary functions entitled to municipal immunity."158 Sorenson therefore stands for the proposition that decisions relating to on-street parking are discretionary and accordingly immune from liability.

As previously noted, the installation of street trees may also make a street more comfortable for pedestrians by slowing traffic and protecting pedestrians from harsh weather. ${ }^{159}$ This decision is also protected by discretionary immunity. In Sims v. Newark, ${ }^{160}$ the plaintiffs were injured when their car was struck by a decaying tree limb as a result of the city's negligent maintenance of street trees. ${ }^{161}$ The court held that because " $[t]$ ree pruning and removal ... involves discretionary decisions at every phase of the process .... The city has immunity when exercising judgment or discretion in its maintenance of

${ }^{153}$ Id. (emphasis added).

${ }^{154}$ See supra note 24. But see supra note 111 (expressing concerns about effects of onstreet parking on bicyclists).

${ }^{155} 621$ A.2d 438, 440 (N.H. 1993).

${ }^{156} I d$. at 438 .

${ }^{157} \mathrm{Id}$. at 439 .

${ }^{158}$ Id. at $439-40$

${ }^{159}$ See BURDEN, supra notes 119-21 and accompanying text.

${ }^{160} 581$ A.2d 524 (N.J. Super. Ct. Law Div. 1990).

${ }^{161} I d$. at 525 . 
trees."162 If tree removal is discretionary, it logically follows that tree installation is equally discretionary and thus immune from liability.

\section{The Role of ITE Guidelines}

Just as compliance with AASHTO guidelines may reduce a government's risk of tort liability, compliance with ITE guidelines may have similar effects. In James v. New York State Bridge Authority, ${ }^{163}$ the plaintiff's husband was killed while driving on a curve with a fifty-five-mile-per-hour speed limit. The plaintiff claimed the state was negligent in failing to set a lower speed limit. ${ }^{164}$ A New York appellate court held that the state's decision was entitled to discretionary immunity because the state based its decision on a report by an engineering firm about the speed limit's safety, and that report was based on ITE studies. ${ }^{165}$ James accordingly stands for the proposition that compliance with ITE studies or guidelines, like compliance with the Green Book, is evidence that roads were maintained in a reasonably safe condition. ${ }^{166}$

As noted above, ITE recently drafted guidelines favoring pedestrianoriented, context-sensitive design. ${ }^{167}$ ITE recommends that mixed-use urban streets have a design speed of thirty to forty miles per hour, ${ }^{168}$ a range at the low end of the Green Book's guidelines, which recommend design speeds of thirty to sixty miles per hour for urban arterials. ${ }^{169}$ While the Green Book urges street-builders to use as high a design speed as practical, ${ }^{170}$ ITE emphasizes that "adequate service levels can be maintained in urban areas with lower operating

${ }^{162}$ Id. at $529-30$.

163743 N.Y.S.2d 151 (N.Y. App. Div. 2002).

${ }^{164} I d$. at 152 (plaintiff alleged that a state agency "was negligent in failing to provide safe speed limits"; the court noted in the opinion that the government "raised the speed limit on the subject curve from 40 miles per hour to 55 miles per hour").

${ }^{165} I d$. at 153 .

${ }^{166}$ Similarly, where state street-design guidelines favor more pedestrian-friendly design, those guidelines are also entitled to judicial deference. See ITE MANUAL, supra note 58, at 10 (noting that some local and state agencies have adopted ITE principles as policies or mandates); MASS. HighWAY DEP'T, supra note 66, at 1.1; Ostendorf v. Kenyon, 347 N.W.2d 834, 838 (Minn. Ct. App. 1984) (state likely to be immune from suit when it complies with its own manuals).

${ }^{167}$ See, e.g., ITE MANUAL, supra note 58 and accompanying text.

${ }^{168} \mathrm{Id}$. at 90 ("[d]esign speed ranges from 30 to $40 \mathrm{mph}$ ").

${ }^{169} \mathrm{Id}$. (proposed design speeds are at "a range consistent [with], but somewhat lower than, the higher end of AASHTO's recommended range for urban arterial streets"); AASHTO 2004, supra note 7, at 470 ("Design speeds for urban arterials generally range from ... 30 to $60 \mathrm{mph}$ ....").

${ }^{170}$ AASHTO 2004, supra note 7, at 67. 
and design speeds."171 While the Green Book further discourages on-street parking, ${ }^{172}$ ITE's manual lists the advantages of on-street parking as well as the disadvantages ${ }^{173}$ and asserts that government design "needs to balance traffic capacity and local access needs when deciding where and when to permit onstreet parking." ${ }^{\text {"174 }}$ Because courts defer to ITE's recommendations as well as those of AASHTO, a government agency that disregards AASHTO guidelines in order to create more pedestrian-friendly streets is likely to avoid tort liability if its decision is supported by the ITE guidelines.

\section{Can AASHTO Guidelines Prevent Reliance on Discretionary Immunity?}

The immunity-related cases cited above did not mention government deviations from AASHTO guidelines. It could be argued, therefore, that transportation planners are not immune from tort liability if they have chosen to disregard AASHTO guidelines, even if planners' decisions were based on the broad policy of making streets safer and more comfortable for pedestrians.

In State v. Day, ${ }^{175}$ the plaintiff was injured in a car crash because of the state's alleged violation of AASHTO guidelines. ${ }^{176}$ A Texas appellate court held that the relevant "AASHTO manual does not create a mandatory duty with regard to the design of the intersection in question; the manual itself provides that the specifications do not create absolute, non-discretionary standards.",177 In other words, the state "had discretion to design the highway contrary to the specifications set out in the AASHTO manual."178 Because Day applied discretionary immunity despite the state's rejection of AASHTO guidelines, it

${ }^{171}$ ITE MANUAL, supra note 58, at 91.

${ }^{172}$ See AASHTO 2004, supra note 7, at 373 (asserting that on-street parking "decreases through-traffic capacity, impedes traffic flow, and increases crash potential"); id. at 483 (stating that " $[\mathrm{z}]$ oning regulations should require ample off-street parking as a condition for approval of a building permit").

${ }^{173}$ See ITE MANUAL, supra note 58, at 130-31 (listing advantages); id. at 132 (noting that on-street parking "can result in a 3 to 30 percent decrease in the capacity of the adjacent travel lane").

${ }^{174}$ Id. at 132.

${ }_{175}^{17}$ No. 09-02-177, 2002 WL 31525359, at *1 (Tex. App. Nov. 14, 2002).

${ }^{176} I d$. at $* 2$ (plaintiff claimed that a driver approaching the intersection where the accident occurred would not "have the minimum sight distance required by AASHTO").

${ }^{177}$ Id. The same is true of the current Green Book. See AASHTO 2004, supra note 7, at xliii ("Sufficient flexibility is permitted to encourage independent designs tailored to particular situations.").

${ }^{178}$ Day, 2002 WL 31525359 , at *2. 
supports the proposition that discretionary immunity protects policy decisions that deviate from Green Book standards.

Similarly, in Schmitz v. Dubuque, ${ }^{179}$ the plaintiff was injured on a bicycle/walking trail and sued the city for negligently designing the trail. ${ }^{180}$ The Iowa Supreme Court noted that the trail violated AASHTO standards ${ }^{181}$ but nevertheless addressed the merits of the city's contention that "irrespective of any negligence, it cannot be held liable because the acts complained of by plaintiff were discretionary." 182 In considering the city's discretionary immunity defense, Schmitz implicitly held that a government agency that disregards AASHTO guidelines may nevertheless rely on the discretionary immunity defense.

At first glance it might appear that Corso v. Laborde ${ }^{183}$ is to the contrary. In Corso, an injured plaintiff's expert testified that the Louisiana Department of Transportation's failure to widen a road to conform to AASHTO standards was negligent, ${ }^{184}$ and the court found evidence of negligence sufficient to support a jury verdict. ${ }^{185}$ It could be argued that under Corso, decisions relating to road width are not protected under discretionary immunity where those decisions are contrary to AASHTO standards.

This interpretation of Corso, however, is incorrect for two reasons. First, the Corso court did not mention discretionary immunity, which implies that the government might not have alleged such immunity and the Corso court might have ruled otherwise had the state raised the defense. Second, the court's finding of negligence was not based solely on the state's failure to widen the road. The plaintiff's expert emphasized that the state should have placed a warning sign 200 feet, rather than 400 feet, from the curve where the plaintiff

${ }^{179} 682$ N.W.2d 70 (lowa 2004).

${ }^{180}$ Id. at 71 .

${ }^{181} \mathrm{Id}$.

${ }^{182}$ Id. The court went on to hold that the city's decision was based solely on cost, and was thus not the sort of policy decision protected by discretionary immunity. Id. at 76 . But see Duncan v. Union Pac. R.R., 790 P.2d 595, 601 (Utah Ct. App. 1990), aff'd, 842 P.2d 832 (Utah 1992) (because highway maintenance and improvement "are predominantly fiscal matters ... we will not hold [transportation officials] negligent for having to strike a difficult balance between the need for greater safety and the burden of funding improvements") (footnote omitted).

${ }^{183} 927$ So. 2d 567 (La. Ct. App. 2006).

${ }^{184}$ Id. at 568.

${ }^{185} I d$. at 569 . The court went on to dismiss the case on causation grounds, holding that the driver's negligence was the true cause of the accident. Id. at 569-70. 
was injured. ${ }^{186}$ The court specifically relied on this testimony, holding that a "reasonable person could well have determined that the road was improperly designed, or at least that the sign was improperly located."187 In other words, the closest the court came to criticizing the state's road-widening decision was a vague reference to "improper design," yet the court specifically mentioned the location of the curve warning sign. Because the Corso court did not explicitly hold that the state's decision with regard to street width was negligent, it does not reject the application of discretionary immunity to street-width decisions. ${ }^{188}$

\section{In the Absence of Immunity}

The discussion above is relevant to states applying discretionary immunity to street design, but a few states seem to reject immunity in highway design cases. ${ }^{189}$ In these states it could be argued that any breach of AASHTO guidelines is likely to constitute an act of negligence. Nevertheless, precedent from at least one state suggests otherwise.

A Michigan statute provides that "each governmental agency having jurisdiction over a highway shall maintain the highway in reasonable repair so that it is reasonably safe and convenient for public travel." ${ }^{\prime 90}$ Under Michigan case law, this statute creates a "highway exception" to governmental tort immunity. ${ }^{191}$ But in Hanson v. Board of County Road Commissioners, ${ }^{192}$ the Michigan Supreme Court made it clear that this statute does not allow unlimited litigation against government agencies. In Hanson, the plaintiff's decedent died in a head-on collision at the crest of a hill, and the plaintiff alleged that the

${ }^{186} \mathrm{Id}$. at 568.

${ }^{187}$ Id. at 569 (emphasis added).

${ }^{188}$ It could also be argued that even discretionary decisions are not immune from liability where a government's decision is clearly unreasonable. For example, liability may be found where government officials were on notice that a street or intersection was dangerous. See Jones v. Miss. Transp. Comm'n, 920 So. 2d 516, 519 (Miss. Ct. App. 2006) (discretionary immunity is inapplicable where the government is "given notice of a dangerous condition"). Pedestrianfriendly streets, though, may actually be safer than those designed for high traffic. See infra Part III. Thus, concerns over notice are unlikely to support liability in cases where a plaintiff challenges streets designed for slow traffic.

${ }^{189}$ See 40 AM. JUR. 2D Highways, Streets and Bridges $\$ 381$ (2008) (discussing cases from Kentucky and Illinois); Jonathan T. Mann, The Narrow Road: Defective Highway Design Claims and the Michigan Highway Exception to Governmental Immunity, 50 WAYNE L. REV. 999 (2004) (describing the law of one such state, Michigan, in detail).

${ }_{190}$ Mich. COMP. LAWS ANN. § 691.1402(1) (West 2000).

${ }^{191}$ See Mann, supra note 189 , at 1003.

192638 N.W.2d 396 (2002). 
road was unsafe for a variety of reasons, including inadequate street width. ${ }^{193}$ The court rejected the plaintiff's claim on the ground that the statute's reference to "maintain[ing] the highway in reasonable repair" means that the highway exception is limited to "failure to repair or maintain the actual physical structure of the roadbed surface,"194 and thus creates no duty to "design, or to correct defects arising from the original design or construction of highways.", Because the statute created no duty to design roads carefully, government officials also had no duty to "improve or enhance existing highways, as by widening existing lanes or banking existing curves; that they augment existing highways, as by adding left-turn lanes."196 In Michigan, as in discretionary immunity states, governments are not liable for negligent street design merely because those roads are too narrow to accommodate high-speed traffic.

Similarly, in Brooks v. Michigan Department of Transportation, ${ }^{197}$ an injured plaintiff alleged that "the narrow width of the shoulder on a sharp curve constituted a failure to maintain or repair the roadway" $" 198$ under the highway exception statute. The Michigan Court of Appeals rejected the plaintiff's claim, explaining that under Hanson, "state and county road commissions have no duty ... to improve upon or correct defects arising from the original design of a roadway and no duty to redesign a roadway." 199

Brooks and Hanson suggest that even in the absence of discretionary immunity, statutes that subject road designers to liability for negligence will be narrowly construed. Moreover, in the absence of clear statutory language to the contrary, government agencies need not be liable for designing a road too narrowly to accommodate speeding motorists.

${ }^{193} I d$. at 397-98 (describing the underlying facts and the plaintiff's claims, including her claim that the government failed "to maintain 160 th Avenue [the street where the crash occurred] at a proper and adequate width ... to provide motorists reasonable margins of error in their driving patterns and allow oncoming vehicles to safely pass each other at the crest of the hill").

${ }^{194} \mathrm{Id}$. at 400 (explaining why exception does not allow claims of inadequate street signage).

${ }^{195}$ Id. at 401.

${ }^{196}$ Id. at 402 (quoting Wechsler v. Wayne County Rd. Comm'r, 546 N.W.2d 690, 694 (Mich. Ct. App. 1996)).

${ }^{197}$ Nos. 232521, 232750, 234213, 235509, 2003 WL 1442457, at *1 (Mich. Ct. App. Mar. $13,2003)$.

${ }^{198} I d$.

${ }^{199}$ Id. at *2. 


\section{B. Even in the Absence of Immunity, the Green Book Allows Pro- Pedestrian Design}

Even if street designers are unable to avail themselves of some type of immunity to protect against liability, it does not follow that the Green Book requires street designers to adopt the high-speed status quo. First, the Green Book itself provides that it is not intended to set forth mandatory guidelines. As noted above, ${ }^{200}$ the foreword to the most recent Green Book states that its guidelines are not intended to "super[s]ede the need for the application of sound principles by the knowledgeable design professional"201 or to preclude "independent designs tailored to particular situations."202

In Riley v. United States, ${ }^{203}$ the U.S. Court of Appeals for the Eighth Circuit interpreted this language to allow deviation from Green Book guidelines. In Riley, a motorist crashed into another vehicle because mailboxes obscured his view of traffic. ${ }^{204}$ The plaintiff sued the United States Postal Service (USPS) for negligent placement of the mailboxes and asserted that USPS failed to follow Green Book recommendations governing intersection design. ${ }^{205}$ Even though the Green Book was incorporated by reference into relevant federal regulations, ${ }^{206}$ the court held that discretionary immunity barred the plaintiff's claim because the "Green Book provisions ... are guidelines and not mandatory." 207 Although Riley was decided in the context of discretionary immunity, the court's language nevertheless supports the broader proposition that the Green Book's language--by its own terms-is not binding upon street designers.

Second, recent language used in the Green Book creates additional flexibility for street designers because it incorporates pro-pedestrian language that transportation planners can balance against the Green Book's pro-speed clauses. For example, the 2004 Green Book emphasizes that street designers should consider the interests of non-drivers as well as drivers. ${ }^{208} \mathrm{~A}$ government agency that is sued for not aggressively accommodating high-speed

${ }^{200}$ See AASHTO 2004, supra note 7, at xliii and accompanying text.

${ }^{201} I d$.

${ }^{202} I d$.

${ }^{203} 486$ F.3d 1030 (8th Cir. 2007).

${ }^{204}$ Id. at 1031.

${ }^{205} I d$. at 1033 (quoting the Green Book, which states that drivers "must have sufficient sight distance to make a safe departure through the intersection area").

${ }^{206}$ Id. (citing 23 C.F.R. $\S 625.4$ (2008)).

${ }^{207}$ Id. (citations omitted).

${ }^{208}$ See supra notes 68-84 and accompanying text. 
traffic can therefore reduce its risk of liability through its use of the Green Book, as long as the decision at issue is motivated by the public interest in protecting non-drivers.

The Green Book's more specific provisions also insulate pro-pedestrian street designers from liability. The Green Book explicitly states that arterial streets need not be wider than four lanes, and that other streets can be as narrow as two lanes. ${ }^{209}$ The Green Book's lane-width standards also accommodate non-drivers' interest in narrower, easy-to-cross streets because they allow eleven-foot lanes on arterials and nine-foot lanes on other streets. ${ }^{210}$ Thus, an engineer who designs an eighteen-foot collector street can claim that her compliance with the Green Book is evidence of non-negligence.

In one respect, the Green Book virtually mandates pro-pedestrian policies when it states that sidewalks should be the norm not only in commercial areas but also in residential areas where pedestrian activity is more likely. ${ }^{211}$ It could be argued, then, that a road designer that fails to build sidewalks is in violation of the Green Book and risks liability. This argument, though, is unlikely to succeed because numerous cases have held that municipalities have no duty to install sidewalks. ${ }^{212}$

In sum, the Green Book's specific recommendations are not binding on transportation planners, and even if they were, they often support the construction of pedestrian-friendly streets. It is significant that the Green Book no longer consistently supports the high-speed status quo.

\section{THE POLICY ISSUE: WHY BOTHER?}

As explained above, American tort law allows transportation planners to build narrower, more pedestrian-friendly streets. It could be argued, however, that such reforms are unwise as a matter of policy because the overwhelming

${ }^{209}$ See supra notes 75-81 and accompanying text.

${ }^{210}$ See supra notes 83-84 and accompanying text.

${ }^{211}$ See supra notes 69-73 and accompanying text.

${ }^{212}$ See, e.g., Bd. of Educ. of Dolton Sch. Dist. 149 v. Miller, 812 N.E.2d 688, 694 (IIl. App. Ct. 2004) ("[I]n the context of tort law, this court has held that public entities do not have a duty to construct sidewalks."); Radzka v. Inc. Vill. of Kings Point, 686 N.Y.S.2d 805, 807 (N.Y. App. Div. 1999) (village "had no duty to install sidewalks"); Braithwaite v. W. Valley City Corp., 921 P.2d 997, 998 (Utah 1996) ("the City has no legal duty to construct sidewalks"). However, these decisions contain no indication that the deciding courts were made aware of AASHTO's endorsement of sidewalks. 
majority of Americans drive to most destinations, ${ }^{213}$ and as such, drivers' interest in fast traffic flow is more important than the safety and comfort of pedestrians and bicyclists. But in fact, even drivers may be safer on pedestrianfriendly streets than on high-speed, auto-oriented streets. Drivers are less likely to notice other drivers when traveling at high speeds and therefore more likely to injure those drivers. ${ }^{214}$ Accordingly, drivers may actually be safer when traveling on streets designed for pedestrians as well as cars.

One recent study examined five years of crash data (1999-2003) for Colonial Drive in Orlando, Florida. The study compared two 0.9-mile-long stretches of the street: a relatively pedestrian-friendly area with four eleven-foot travel lanes with on-street parking, and a nearby area with fifty-foot-wide streets ${ }^{215}$ without on-street parking. ${ }^{216}$ Even though the two areas had equal traffic volume and were of equal length, ${ }^{217}$ the wider section of Colonial Drive had six fatal crashes - three of which involved pedestrians - while the narrower section had none. ${ }^{218}$ Moreover, the more walkable section of Colonial Drive also had $31 \%$ fewer injuries from mid-block crashes and $11 \%$ fewer total midblock crashes. ${ }^{219}$ The study also compared the relatively walkable section of Colonial Drive with a conventionally designed ten-mile section of that street; the walkable section had $35 \%$ fewer injurious mid-block crashes per mile and $25 \%$ fewer total mid-block crashes. ${ }^{220}$

${ }^{213}$ Ronda Larson, The End of an Era: Suburban Village Aversion in Citizens for Mount Vernon v. City of Mount Vernon, 74 WASH L. REV. 367, 376 n.53 (1999) (stating that "[e]ightysix percent of trips taken by Americans are by car").

${ }_{214}$ See supra notes 37-43 and accompanying text (noting that the dangers of high speed apply to all road users, not just pedestrians).

${ }_{215}$ See Eric Dumbaugh, Safe Streets, Livable Streets, 71 J. AM. Plan. Ass'N 283, 288-90 (2005) (describing study and describing portions of Colonial Drive studied).

${ }^{216} \mathrm{Id}$. at 290 (comparing street widths of two portions of Colonial Drive and noting, in particular, that the pedestrian-oriented section of the street had parking lanes, while the more conventional section had paved shoulders).

${ }_{217}^{17}$. (both sections of the street were 0.9 miles long; both had between 46,000 and 47,000 vehicles per day passing through them).

${ }^{218} I d$. at 288.

${ }^{219}$ Id. at 290 . The study focused on mid-block crashes, perhaps because crashes at intersections may be the result of the design of the intersecting street rather than the result of the design of Colonial Drive alone. I note, however, that the number of crashes at intersections for both portions of Colonial Drive were roughly comparable. Id. (twenty-one crashes per intersection in pedestrian-friendly part of Colonial Drive, as opposed to nineteen crashes per intersection in conventionally designed portion of street).

${ }^{220}$ Id. at 291. 
A study involving residential streets reached similar conclusions. The study analyzed 20,000 accident reports from the city of Longmont, Colorado, approximately thirty-five miles north of Denver, ${ }^{221}$ and discovered that thirtysix-foot-wide residential streets had more than five times as many accidents per mile per year than twenty-four-foot-wide streets. ${ }^{222}$ These data make clear that pedestrian-friendly streets designed for low speeds are safe for drivers as well as pedestrians. ${ }^{223}$

Furthermore, "drivers" and "pedestrians" are not mutually exclusive categories. Most drivers walk outside at some point during their lives and-to the extent that walking is safe and comfortable-these driver/pedestrians experience the benefits of such safety and comfort. To the extent that pedestrian-friendly streets encourage people to walk to some places to which they would otherwise drive a car, congestion on America's streets as well as air pollution is reduced. ${ }^{224}$

\section{CONCLUSION}

American transportation planners have frequently designed streets in order to accommodate automobiles operating at high speeds. Often, these streets are not safe or convenient for pedestrians and other non-drivers. Ironically, one reason road designers continue to build high-speed streets is their concern about

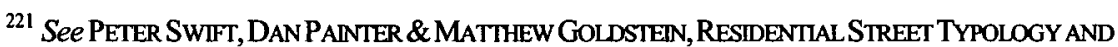
INJURY ACCDENT FREQUENCY (1997), available at http://massengale.typepad.com/ venustas/files/SwiftSafetyStudy.pdf.

${ }^{222} I$ Id. at tbl.2.

${ }^{223}$ It could be argued that the low crash rates of high-speed interstate highways suggest otherwise. Interstate highways have no pedestrians; thus, design features that would make a normal street dangerous are not as harmful on interstates. See Dumbaugh, supra note 215, at 295 (noting that interstates "limit their use to a single user type-motorists"). Moreover, many interstates have no intersections, and thus have fewer points where vehicles traveling in different directions could collide. See Mitch Tobin, Interstates Relatively Safe, Experts Say, ARIZ. DAILY STAR, Mar. 12, 2006, available at http://www.azstarnet.com/sn/byauthor/119685.

224 See supra note 51 and accompanying text (noting that reduction in car trips might reduce congestion and pollution). It could be argued, of course, that most people will drive rather than walk no matter how streets are designed. But this argument is rebutted by the fact that even within the narrow universe of large American cities, some cities have far more pedestrians than others. See Men's Fitness, 2009 Fittest Cities: \#1 Salt Lake City, UT, http://www.mensfitness.com/lifestyle/193?page=2 (residents of Salt Lake City "walk for fitness 109 percent more than residents of the average city in our survey"); Men's Fitness, 2009 Fattest Cities in America: 25 Towns in Need of a Fitness Overhaul, http://www.mensfitness.com/ lifestyle/216 (by contrast, residents of Oklahoma City "are 28 percent less likely to participate in fitness walking than average").
} 
tort liability-in particular, their fear that if they deviate from the Green Book's guidelines in building more pedestrian-friendly streets, they may face extensive litigation if a driver is injured on a street that failed to accommodate her level of speed.

This concern is no longer persuasive for two reasons. First, discretionary immunity protects government officials from negligence liability for decisions to build narrower, low-speed streets provided those decisions are based on policy judgments, and a decision to make a street safer for pedestrians is recognized as such a policy judgment. Second, recent versions of street-design manuals grant transportation designers considerable flexibility to build calmer, more pedestrian-friendly streets. An engineer who acts in accordance with street-design manuals may therefore build streets that accommodate non-drivers as well as drivers without risking liability merely for making decisions that accommodate non-drivers. 
